\title{
Pangolins in south-west Nigeria - current status and prognosis
}

\author{
Olufemi A. Sodeinde and Segun R. Adedipe
}

\begin{abstract}
Despite being officially listed as endangered in Nigeria, pangolins are still hunted in Ogun State, where deforestation has fragmented and reduced their forest habitat. To investigate pangolin status in the state, the authors interviewed hunters, forest workers and market traders selling wild animals or their parts for medicinal use. The authors also counted pangolins stocked by market traders during weekly visits to markets in six towns/villages. Only one of Nigeria's three pangolin species, Manis tricuspis, was encountered frequently. Hunters' reports and evidence of forest destruction suggest that even this species is becoming rare. An estimate of extinction-susceptibility shows that pangolins are at fairly high risk. Creation of sanctuaries for pangolins and other important sympatric vertebrates in forest relicts in south-west Nigeria and the establishment of semicaptive pangolin populations are advocated.
\end{abstract}

\section{Introduction}

There are seven living species of pangolins, all members of a single genus - Manis. Four occur in Africa (Simpson, 1945; Emry, 1970), three of these in West Africa: tree pangolin $M$. tricuspis, long-tailed pangolin $M$. tetradactyla and giant ground pangolin M. gigantea (Booth, 1960; Dorst and Dandelot, 1970; Happold, 1987). The fourth African species, Temminck's ground pangolin $M$. temminckii is found in north, east and southern Africa (Dorst and Dandelot, 1970).

Manis temminckii is listed on Appendix I of CITES and the other three African species on Appendix III (for Ghana only) (Emonds, 1981), while all four species are listed in class B of the 1968 African Convention on Nature and Natural Resources (Burhenne, 1970). In addition, the three West African species are listed in Schedule 1 of Nigeria's Decree (Law) No. 11: Control of International Trade in Endangered Wild Species of Flora and Fauna, 1985 (Anon., 1985). Animals in this schedule are perceived as needing protection against over-exploitation through trade, which may further endanger species threatened with extinction or cause those not threatened to be- come so (Article II of CITES in Emonds, 1981; Anon., 1985), and are protected by law. Animals in these categories receive only nominal protection in Nigeria because the laws are either obsolete or are not properly enforced (Afolayan, 1980; Anadu et al., 1988).

Manis tricuspis and $M$. tetradactyla are arboreal and live in the High Forest zone, but the latter species is not so widespread in drier forests and is diurnal (Booth, 1960). Manis gigantea is nocturnal, like $M$. tricuspis, but occurs in both forest and savannah. Despite their endangered status in Nigeria, surveys to investigate their status there have been infrequent. Cozens and Marchant (1952) reported hunters in Owerri Province, south-east Nigeria, as saying that pangolins were common, while Sikes (1966) reported that they were rare in the Nigerian middlebelt. Six out of nine localities in which $M$. tricuspis was reported in southern Nigeria (total Nigerian localities $=12$ ) are in the south-west (Happold, 1987). Mason (1940) recorded the rarer $M$. tetradactyla in Ohosu Forest Reserve and Anadu et al. (1988) listed the species among those caught by hunters in Bendel State (now Edo and Delta States), also in the south-west. Pangolins are eaten (Anadu et al., 1988; Asibey and Child, 1990) and are 


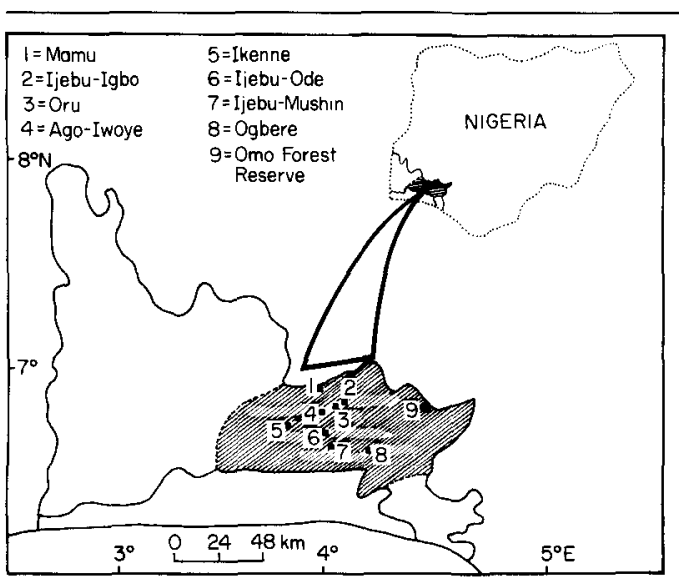

Figure 1. Map showing location of the study area (cross hatched) in Ogun State, south-west Nigeria.

used in traditional medicine, 'juju' (Hayman, 1954; Walker, 1975; Ntiamoa-Baidu, 1987).

Deforestation for timber, urban development, road and oil-pipeline construction, and shifting agriculture have extensively modified the forest habitats of pangolins (Umeh, 1986). Only a few relicts of undisturbed and little disturbed rain forest remain, mostly in forest reserves, which in 1978 constituted 20 per cent of the lowland rain forest, which then covered $95,372 \mathrm{sq} \mathrm{km}$, with $2732 \mathrm{sq} \mathrm{km}$ being in Ogun State (Umeh, 1986).

This study was prompted by the occurrence of pangolins among species sold by traders in juju ingredients and by bushmeat sellers in parts of Ogun State, south-west Nigeria, and a widely expressed view by indigenes that pangolins are common in the State. The objectives were: (i) to determine the status of pangolins in the area; (ii) to investigate the degree to which they are utilized; and (iii) to assess the threats to their survival.

\section{Methods}

\section{Market survey and interviews}

Every week between November 1988 and April 1989 we visited special markets held every 5 days at each of the following southwestern Nigerian towns/villages: Ago-Iwoye,
Atikori, Ijebu-Igbo, Ijebu-Imushin, Ijebu-Ode, Mamu and Oru (Figure 1). These markets, which are held in addition to the regular daily markets, differ in that traders and shoppers from neighbouring towns/villages also attend. Ago-Iwoye and Ijebu-Ode were revisited in November 1991 and June 1992. Pangolins found on the juju stalls of market women trading in whole animals and their parts on each special market day were counted. The pangolins were commonly delivered alive to market women.

We interviewed 30 market women, 10 hunters and six forest workers using a prepared questionnaire. From market women we collected information on the species involved, the source, how long they had been in captivity, seasonal availability, uses of pangolin meat and parts, awareness of Decree No. 11, and cost and selling prices. Hunters and forest workers were asked about the habitats of pangolins, time of capture, capture success, favoured trees for arboreal species, hunting regime, age-class caught, relative abundance and species caught. Selling prices of undressed carcasses of pangolins and other animals were obtained in June 1992 from five bushmeat sellers.

\section{Assessing relative abundance}

Mammals caught in the Omo Forest Reserve (Figure 1), the main hunting ground in the Ijebu area of Ogun State, were enumerated. Near the reserve, data collection centres were set up at three settlements where about 60 hunters lived, although only 45 on average hunted each week. We visited each centre weekly for 20 weeks between February and July 1990 and recorded the following information: the total number of each species caught by a total of 45 hunters at the three settlements $(n)$; the average number of animals caught per settlement $(n / 3 \times 20)$ and the average number caught per hunter per week $(n / 45 \times 20)$. The frequency of capture for each species was calculated by the number of weeks (out of a total of 20 weeks) in which each species was brought to the collection centres. 
Table 1. Extinction-susceptibility rating of pangolins (Manis spp.) based on known attributes of extinctionprone species

\begin{tabular}{|c|c|c|c|}
\hline Attributes & Extinction-prone species & Pangolins & Rating \\
\hline Trophic level & Usually top of food chain & $\begin{array}{l}\text { Insect eater } \\
\text { (Cansdale, 1947; Menzies, 1963) }\end{array}$ & 2 \\
\hline Body size & Large to very large & $\begin{array}{l}\text { Moderate, adults } 43 \mathrm{~cm} \text { head and } \\
\text { body (Rahm, 1956) }\end{array}$ & 2 \\
\hline $\begin{array}{l}\text { Taxonomic } \\
\text { uniqueness }\end{array}$ & Monotypic & $\begin{array}{l}\text { Monotypic family and genus } \\
\text { (Simpson, 1945; Emry, 1970) }\end{array}$ & 4 \\
\hline Reproductive rate & Low, very low & $\begin{array}{l}\text { One young per female, gestation } \\
\text { period c. } 6 \text { months (Menzies, 1967; } \\
\text { 1971); monogamous (Pagès, 1972) }\end{array}$ & 3 \\
\hline $\begin{array}{l}\text { Breeding and } \\
\text { longevity in } \\
\text { captivity }\end{array}$ & Poor & $\begin{array}{l}\text { No conception in captivity, do } \\
\text { not survive long (usually }<3 \text { months) } \\
\text { (Menzies, 1963) }\end{array}$ & 5 \\
\hline $\begin{array}{l}\text { Population } \\
\text { distribution }\end{array}$ & Fragmented & $\begin{array}{l}\text { Fragmented (Dorst \& Dandelot, 1970; } \\
\text { Happold, 1987; this study) }\end{array}$ & 3 \\
\hline $\begin{array}{l}\text { General habitat } \\
\text { distribution }\end{array}$ & $\begin{array}{l}\text { Fragmented, surrounded } \\
\text { by incompatible land-use }\end{array}$ & $\begin{array}{l}\text { Forests and savannah (Booth, } 1960 \\
\text { Happold, 1987) in discontinuous areas }\end{array}$ & 3 \\
\hline Habitat alteration & Continuous and high & Continuous; at high rate (Umeh, 1986) & 5 \\
\hline Habitat requirements & Special or specific & $\begin{array}{l}\text { Restricted in diet (Cansdale, 1947; } \\
\text { Menzies, 1963), found on trees infested } \\
\text { with preferred prey (Pagès, 1970) }\end{array}$ & 3 \\
\hline Insularity & Pronounced/high & $\begin{array}{l}\text { Local populations discontinuous } \\
\text { (Happold, 1987; this study) }\end{array}$ & 3 \\
\hline Hunting pressure & High & Persistent (Walker, 1975; this study) & 4 \\
\hline $\begin{array}{l}\text { Economic/ } \\
\text { medicinal value }\end{array}$ & High or priceless & $\begin{array}{l}\text { Flesh eaten, scales and other parts used } \\
\text { for charms, ornaments and medicinal } \\
\text { compounds (Hayman, 1954; Walker, 1975; } \\
\text { this study) }\end{array}$ & 4 \\
\hline Extinction Risk Index & & & 0.68 \\
\hline
\end{tabular}

\section{Rating for susceptibility to extinction}

Attributes known to predispose animal species to endangerment or extinction (see Anon, 1980; Oates, 1982; Choudhury, 1988; Reeves et al., 1988) were used to assess the vulnerability of pangolins to extinction (Table 1). Each attribute was assigned a weight based on its potential to cause extinction, ranging from a maximum of 5 (where extinction risk is highest) to 0 (where the attribute has no impact). Species at highest risk of extinction would score the maximum weight for each attribute and an overall Extinction Risk Index (ERI) of
1, where ERI is the summed scores of all attributes divided by the total possible scores (60). Pangolins were rated on each attribute based on published information and the findings of this study.

\section{Results}

\section{Species occurrence and numbers}

Only $M$. tricuspis was found in the markets and all individuals recorded had head-andbody lengths of at least $200 \mathrm{~mm}$. Market 
Table 2. Number of Manis tricuspis recorded in markets in Ogun State, Nigeria, November 1988-April 1989

\begin{tabular}{lllllllll}
\hline & \multicolumn{2}{c}{ Markets } & & & & & & \\
Month & Mamu & Oru & $\begin{array}{l}\text { Ijebu- } \\
\text { Igbo }\end{array}$ & $\begin{array}{l}\text { Ijebu- } \\
\text { Imushin }\end{array}$ & Atikori & $\begin{array}{l}\text { Ijebu } \\
\text { Ode }\end{array}$ & $\begin{array}{l}\text { Ago- } \\
\text { Iwoye }\end{array}$ & $\begin{array}{l}\text { Monthly } \\
\text { total }\end{array}$ \\
\hline November 1988 & 6 & 1 & 3 & 2 & 3 & 3 & 3 & 20 \\
December 1988 & 4 & 2 & 5 & 2 & 3 & 3 & 3 & 28 \\
January 1989 & 8 & 1 & 5 & 3 & 5 & 5 & 4 & 37 \\
February 1989 & 4 & 1 & 2 & 2 & 1 & 1 & 2 & 20 \\
March 1989 & 4 & 0 & 3 & 1 & 3 & 3 & 1 & 16 \\
April 1989 & 6 & 0 & 3 & 2 & 4 & 4 & 1 & 21 \\
Market total & 32 & 5 & 21 & 12 & 19 & 19 & 14 & 142 \\
\hline
\end{tabular}

women bought pangolins from hunters, forest reserve workers, employees of timber dealers and secondary buyers, usually 1-3 days before market days. The number of pangolins supplied each month in the sampled area ranged between 16 and 37 (Table 2), the average being 24.

All the hunters hunted at night and four also hunted in the daytime. Nine ( 90 per cent) said that pangolins are caught fortuitously usually at night, and all reported increasing difficulty in catching them. Eight hunters ascribed this to the animals being rarer while two said the animals had also become less widespread. Nine hunters caught $M$. tricuspis only, while the tenth, who also hunted during the day, had also caught $M$. tetradactyla once.
None of the hunters saw or caught $M$. gigantea, although a retired hunter we interviewed (not among the 10 sampled) claimed he caught one in the Ogbere area of Ogun State (Figure 1) prior to 1979 (exact date not remembered).

All the hunters said that pangolins were more available or caught more easily during the dry season (November-March) than in the rainy season (April-October), and that they caught pangolins of all ages. However, only subadult (pre-reproductive) and adult (reproductive) $M$. tricuspis were seen on the stalls of market women surveyed. A female pangolin, with head-and-body length of $416 \mathrm{~mm}$ and body weight of $1.61 \mathrm{~kg}$, which was acquired on 12 December 1988 gave birth to one young

Table 3. Frequency of capture and other indices of abundance of pangolins and other mammals caught in the Omo Forest Reserve, south-west Nigeria, by hunters in the Omo area, February-July 1990

\begin{tabular}{|c|c|c|c|c|}
\hline \multirow[b]{2}{*}{$\begin{array}{l}\text { English and } \\
\text { scientific names }\end{array}$} & \multirow[b]{2}{*}{ Frequency } & \multirow[b]{2}{*}{$\begin{array}{l}\text { Total } \\
\text { catch }\end{array}$} & \multicolumn{2}{|c|}{ Average catch per hunting trip } \\
\hline & & & $\begin{array}{l}\text { / collection } \\
\text { centre }\end{array}$ & /hunter \\
\hline Bushbuck Tragelaphus scriptus & 17 & 348 & 5.80 & 0.39 \\
\hline Maxwell's duiker Cephalophus maxwelli & 17 & 356 & 5.93 & 0.40 \\
\hline Red-flanked duiker Cephalophus rufilatus & 14 & 171 & 2.85 & 0.19 \\
\hline Grasscutter Thryonomys swinderianus & 13 & 243 & 4.05 & 0.27 \\
\hline Brush-tailed porcupine Atherurus africanus & 13 & 118 & 1.97 & 0.13 \\
\hline White-bellied pangolin Manis tricuspis & 11 & 110 & 1.83 & 0.12 \\
\hline Patas monkey Erythrocebus patas* & 4 & - & - & - \\
\hline Olive baboon Papio anubis* & 1 & - & - & - \\
\hline Tree hyrax Dendrohyrax dorsalis* & 1 & - & - & - \\
\hline Striped duiker Cephalophus doriea* & 2 & - & - & - \\
\hline Palm squirrels Epixerus ebii ${ }^{*}$ & 5 & - & - & - \\
\hline
\end{tabular}

* Probably under-reported and not commonly hunted; only animals landed were enumerated.

Source: O. A. Sodeinde and O. A. Aderogba, unpubl. data. 
on 14 December 1988, an indication that pangolins are born during the hunting season.

\section{Relative abundance}

Data collected during a separate study (February-July, 1990) on the abundance of pangolins relative to other mammals in Omo Forest Reserve are presented in Table 3. Pangolins were least abundant among those species caught regularly.

\section{Habitat}

The consensus of forest workers and hunters was that pangolins sold to market women were caught mostly in forest reserves, specifically Omo Forest Reserve, and relict forests in the Ijebu area. Pangolins were found mainly on ant-infested trees. Four forest workers and nine hunters claimed that they also caught pangolins on abandoned or infrequently harvested oil palm trees (Elaeis guineensis) in secondary forests.

\section{Values and perceived conservation status}

None of the 46 respondents was aware of the endangered status of pangolins nor that there is a law prohibiting consumptive use of the species. Respondents indicated that pangolins are valuable to humans in three ways: as food, as medicine and as a source of income. This information is presented in Table 4. Eight of 10 respondents (four hunters, six market women)

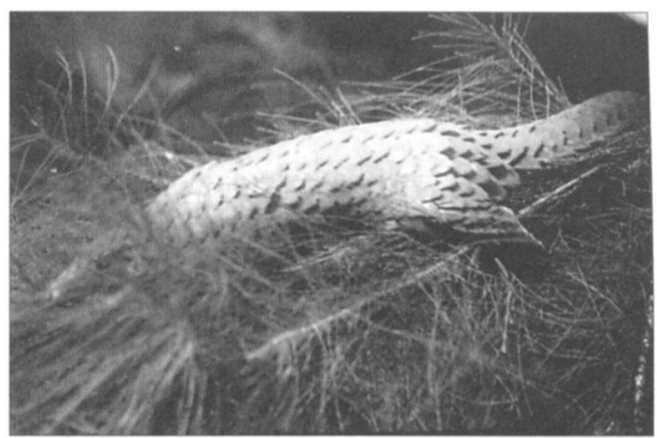

A white-bellied pangolin acquired from one of the markets (O. A. Sodeinde).

interviewed in November 1991/June 1992 said that use of pangolins for juju was more prevalent than use for food, the remaining two were undecided. The six market women told us that pangolin meat is eaten as part-requirement for juju recipes.

Pangolins and other wild animals yield substantial income to hunters, market women and bushmeat sellers (Table 5). Hunters claimed that they sell more pangolins to market women than to bushmeat sellers. They attributed this to the readiness of the market women to buy fresh or badly wounded pangolins of any size whereas bushmeat sellers prefer to buy large, fresh animals.

\section{Susceptibility to extinction}

The extinction-susceptibility rating of pangolins (Table 1) shows that pangolins are vulnerable. Their scores for most attributes were

Table 4. Economic and other values of pangolins with some associated uses or benefits

\begin{tabular}{ll} 
Value & Uses or benefits \\
\hline Food & Meat consumed as a delicacy and source of protein \\
Medicinal & 1. Smoke from burning scales used to repel tailor ants (Formicidae) \\
& 2. Burnt scales mixed with honey, used as an expectorant \\
& 3. Burnt scales taken orally as part of ritual to facilitate childbirth (pangolin placentas are \\
& 4. The head, with eyes intact, used in preparation to treat kleptomania \\
& 5. Whole animal or parts used with appropriate herbs for good fortune \\
Economic & Pangolins and other animals provide source of income for: \\
& 1. Market women selling animals for juju \\
& 2. Bushmeat sellers who trade in smoked carcasses of game animals \\
& 3. Hunters who catch animals for sale to secondary users
\end{tabular}


Table 5. Prices (in Naira) of undressed carcasses of pangolins and other game animals sold by bushmeat sellers (A), and price ranges of pangolins sold by hunters and market women (B) in south-west Nigeria during selected years

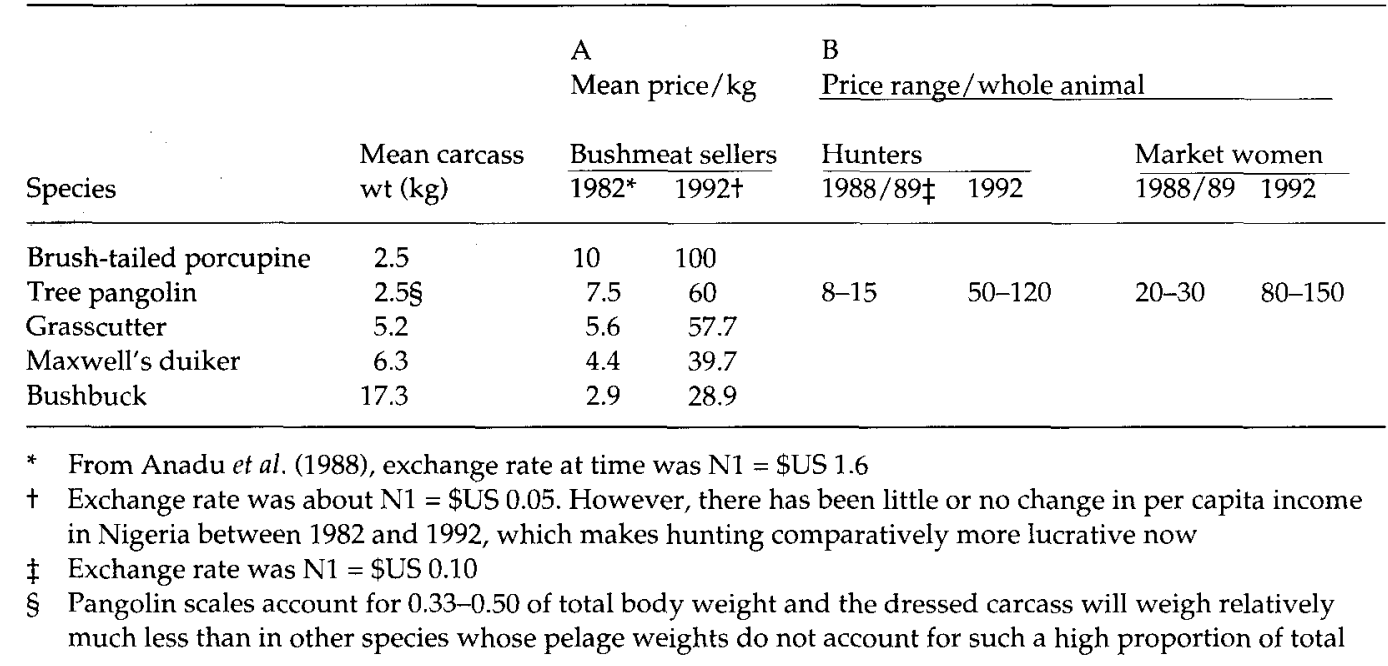

high and the high ERI $(0.68)$ reflects the pressures on these animals and indicates that the risk of losing remaining populations is fairly high, especially because very little is known about their population dynamics and ecology.

Among the external factors responsible for the high index, hunting pressure and habitat alteration/destruction seem especially important. Hunting, like the associated trade in game animals, is an organized economic activity in Nigeria and hunting pressure is not likely to abate unless the co-operation of hunters' associations in the enforcement of hunting regulations is enlisted (see Anadu et al., 1988). Although comparable data on trade in wild animals for medicinal uses is not available, annual trade in bushmeat in Nigeria has been estimated as Naira30 million (1969), Naira100 million (1971) and Naira300 million (1988) (see Anadu et al., 1988).

In Ogun State, dereservation of natural forests for agriculture and other purposes, and their exploitation for timber has further reduced forest habitats. Umeh (1986) estimated the average annual timber harvested from the State as 111,264 cu m, but one-quarter as much again is removed illegally. Umeh (1986) did not indicate the proportion clear-felled or selectively logged, although Schmidt (1987) observed that in Nigeria, trees are mainly selectively logged and this occurs at an average of $5-35 \mathrm{cu} \mathrm{m} / \mathrm{ha} / \mathrm{yr}$.

\section{Prognosis}

\section{Species occurrence and status}

Although one hunter claimed he caught $M$. tetradactyla, the consensus is that the species is rare. Anadu et al. (1988) reported that the species was rare in Bendel State (now Edo and Delta States), south-west Nigeria. Its status and that of $M$. gigantea in Ogun State need to be ascertained. Happold (1987) did not include $M$. gigantea among species present in Nigeria and he emphasized that nothing is known about $M$. tetradactyla in the country. Hunters' reports and evidence of forest destruction suggest that $M$. tricuspis is becoming rare. The capture of reproductive and pre-reproductive individuals could lower the reproductive potential of remaining populations if allowed to continue unchecked.

\section{Values/benefits}

From indications in this study, pangolins will 
continue to be caught whenever the opportunity presents itself. Use of pangolins for medicinal purposes appears to be more important than for food. Ntiamoa-Baidu (1987) listed pangolins among animals used for medicine, but not among those sold for consumption. This could be due to beliefs regarding the efficacy of preparations involving pangolins, the prevalence of the human conditions for which the preparations are used or because the meat is relatively expensive, compared with pork, which sells for N20.00/ kg and beef at $\mathrm{N} 20-\mathrm{N} 40 / \mathrm{kg}$ (Table 5). Although the use of game animals for juju is acknowledged (see Ntiamoa-Baidu, 1987; Anadu et al., 1988), surveys of trade in animals used for juju are very few. Happold (1987) cited only one unpublished report on this topic, in contrast to four on the bushmeat trade. The high price that pangolins attract for either use will encourage their extirpation.

\section{Susceptibility to extinction}

Demographic characteristics that predispose pangolins to endangerment (for example, their low reproductive rate) could be considered in managing populations for conservation. For example, the breeding season could be closed to hunting to enhance recruitment. In southwest Nigeria, the breeding season appears to be the dry season. Menzies (1971) acquired a female pangolin on 1 November 1965, which gave birth on 3 November 1965. This compares well with our December dates. Other factors, such as hunting and habitat degradation, alteration or fragmentation (Sikes, 1974; Reeves et al., 1988) could be checked by legislation and better planning. Wildlife legislation designed to protect endangered species in Nigeria is ineffective and flawed (Afolayan, 1980; Anadu et al., 1988; Lowe and Lowe, 1992) and needs to be reviewed and amended.

The hunting of endangered species within forest reserves shows, as Oates (1982) observed, that hunting is uncontrolled in these enclaves. Managers of forest reserves should be given a stronger mandate to protect the animals. The Omo Forest Reserve, where hunters claimed they caught most pangolins, has other interesting fauna worth protecting. Among these are the endemic (Nigerian) guenon Cercopithecus erythrogaster (Oates, 1985), monitor lizard Varanus niloticus, Nile crocodile Crocodylus niloticus, royal python Python regius, palm squirrels and brushtailed porcupine Atherurus africanus, all of which are endangered in Nigeria (Schedule 1, Decree No. 11).

\section{Recommendations}

To verify the status of pangolins we would recommend intensive field surveys in relict forest in Ogun State and other parts of Nigeria. This should be followed by establishment of sanctuaries in areas with viable populations of pangolins and other rain-forest fauna with which they are sympatric. Specifically, we strongly recommend that a wildlife sanctuary be established in the least disturbed part of Omo Forest Reserve.

To relieve pressure on populations of pangolins in the wild, semi-captive maintenance of the species in natural areas is advocated.

Trade in wild animals for medicinal purposes is poorly inventoried, unlike the bushmeat trade. A more intensive survey of the network of market women trading in wild animals and their parts, the species stocked and the economics of the trade is urgently needed to enable a better assessment of the impact of this trade on wildlife in general and pangolins in particular.

Finally, financial and logistic support by governments and NGOs are vital to the success of conservation programmes. Support could be given through provision of law enforcement aids (e.g. vehicles, walkie-talkies), documentary production expertise and field equipment.

\section{Acknowledgments}

We would like to thank J. F. Oates (Hunter College, CUNY, New York), A. Bräutigam, (IUCN Species Survival Commission Trade Specialist Group), and an anonymous referee for helpful comments and suggestions on earlier drafts of the manuscript, and 
J. F. Oates for providing some of his relevant reprints. A. Adefuke assisted in administering questionnaires and Ogunseye in drawing the map.

\section{References}

Afolayan, T.A. 1980. A synopsis of wildlife conservation in Nigeria. Environ. Conserv. 7, 207-212.

Anadu, P.A.., Elamah, P.O. and Oates, J.F. 1988. A bushmeat trade in southwestern Nigeria. Human Ecology, 16, 199-208.

Anon. 1980. World Conservation Strategy: Living Resource Conservation for Sustainable Development. IUCN-UNEP-WWF.

Anon. 1985. The Endangered Species (Control of International Trade and Traffic) Decree No. 11 of 1985. Nigerian Conservation Foundation.

Asibey, E.O.A. and Child, G.S. 1990. Wildlife management for rural development in sub-saharan Africa. Unasylva, 41, 3-10.

Booth, A.H. 1960. Small mammals of West Africa. West African Nature Handbooks, Longmans, London.

Burhenne, W.E. 1970. African Convention on Conservation of Natural Resources. Biol. Conserv. $2,105-114$

Cansdale, G.S. 1947. West African tree pangolins. Zoolife, 2, 102-105.

Choudhury, A. 1988. Priority ratings for conservation of Indian primates. Oryx, 22, 89-94.

Cozens, A.B. and Marchant, S.M. 1952. A contribution to the fauna of the Owerri Province. Niger. Fld. 17, 70-79, 116-130.

Dorst, J. and Dandelot, P. 1970. A Field Guide to the Larger Mammals of Africa. Collins, London.

Emonds, G. 1981. Guidelines for National Implementation of the Convention on International Trade in Endangered Species of Wild Fauna and Flora. IUCN Environmental Policy and Law Paper No. 17.

Emry, R.J. 1970. A North American Oligocene pangolin and other additions to the Pholidota. Bull. Amer. Mus. Nat. Hist. 142, 457-510.

Happold, D.C.D. 1987. The Mammals of Nigeria. Oxford University. Press, Oxford.

Hayman, R.W. 1954. Pangolins. Zoolife, 9, 12-15.

Lowe, J. and Lowe, R.G. 1992. Decree No. 36, National Parks Decree, 1991. Niger. Fld. 57, 2-5.

Mason, P.F. 1940. A brief faunal survey of northwestern Benin. Niger. Fld. 9, 17-22.

Menzies, J.I. 1963. Feeding pangolins, Manis spp., in captivity. Int. Zoo Ybk. 4, 126-128.
Menzies, J.I. 1967. A preliminary note on the birth and development of a small-scaled tree pangolin, Manis tricuspis at Ife University Zoo. Int. Zoo Ybk. 7, 114 .

Menzies, J.I. 1971. The birth in captivity of a tree pangolin (Manis tricuspis Rafinesque) and observations on its development. Niger. J. Sci. 5, 77-84.

Ntiamoa-Baidu, Y. 1987. West African wildlife: a resource in jeopardy. Unasylva, 39, 27-35.

Oates, J.F. 1982. In search of rare forest primates in Nigeria. Oryx, 16, 431-436.

Oates, J.F. 1985. The Nigerian guenon, Cercopithecus erythrogaster: ecological, behavioral, systematic and historical observations. Folia primatol. 45, $25-43$.

Pagès, E. 1970. Sur l'ecologie et les adaptations de l'oryctérope et des pangolins sympatrique du Gabon. Biol. Gabon. 6, 27-92.

Pagès, E. 1972. Comportement maternal et développement du j'eune chez un pangolin arboricole (M. tricuspis). Biol. Gabon. 8, 63-120.

Rahm, U. 1956. Notes on pangolins of the Ivory Coast. J. Mammal. 37, 531-537.

Reeves, R.R., Tubogu-Metzger, D. and Kapindi, R.A. 1988. Distribution and exploitation of manatees in Sierra Leone. Oryx, 22, 75-84.Schmidt, R. 1987. Tropical rain forest management: a status report. Unasylva, 39, 2-17.

Sikes, S.K. 1966. The tricuspid tree pangolin (Manis tricuspis): its remarkable tongue complex. Niger. Fld. 31, 99-110.

Sikes, S.K. 1974. How to save the mermaids. Oryx, 12, 465-470.

Simpson, G.G. 1945. The principles of classification and a classification of mammals. Bull. Amer. Mus. Nat. Hist. 85, 1-350.

Umeh, L.I. 1986. Deforestation: its extent and effects on Nigeria. In The Challenge of Deforestation in Nigeria. Proceedings of the 1986 Annual Conference of Forestry Association of Nigeria (ed. A. B. Oguntala), pp. 38-48. Forestry Assoc. of Nigeria.

Walker, E.P. 1975. Pangolins. In Mammals of the World (eds R. M. Nowak and J. L. Paradiso), Vol. 1. pp. 504-505. Johns Hopkins Press, Baltimore, 2 vols.

Olufemi A. Sodeinde and Segun R. Adedipe, Department of Biological Sciences, Ogun State University, PMB 2002, Ago-Iwoye, Nigeria. 